\title{
Perception And Use Of Social Media For Information Sharing Among Health Workers In General Hospitals In Ibadan, Oyo State
}

\author{
Eguavoen, E.O. (Ph.D) \\ Kenneth Dike Library,University Of Ibadan, Nigeria
}

\begin{abstract}
Social Media Are Regarded As Important Tools For Information Sharing Geared Towards Solving Social And Environmental Problems As They Have Been Described As Impetus To Solving Complex Issues In Service Delivery In Any Organisation Such As Educational, Health, Commerce And Others. The Study Set Tofind Out The Health Workers' Perception Of The Use, Frequency Of Use As Well As The Relationship Between Perception And Use Of Social Media For Information Sharing By Health Workers In The General Hospitals In Ibadan, Oyo State. Descriptive Survey Research Design Of Correlational Type Was Adopted Using A Sample Size Of 301 Out Of Population Of 541 Health Workers In The General Hospitals Named;Adeoyo State Hospital, Yemetu,Jericho Nursing Home,Adeoyo Hospital Ring Road And Oni And Sons.A Structured Questionnaire Titled; Research Questionnaire For Health Workers Was Used For Data Collection.Data Collected Wasanalysed Using Descriptive And Inferential Statistics. The Results Revealed That Health Workers' Perception To Information Sharing To The Use Of Social Media Is Positive And That There Was No Significant Relationship Between The Health Workers' Perception And Their Use Of Social Media For Information Sharing In The General Hospitals. Arising From These, Recommendations Were Made That Specific Professional Social Media Platform Be Created For The Health Care Practitioners In The General Hospitals And That Health Workers Intending To Use Social Media Must Ensure That Professional Interactions Between/Among Other Health Care Professionals, Including The Transmission Of Any Health Data, Satisfy The Local Policy Or Legislation.
\end{abstract}

Keywords: Perception, Use, Social Media, Information Sharing, Health Workers.

\section{INTRODUCTION}

The Emergence Of Information Sharing As An Ingredient For Solving Social And Environmental Problems Across Organisations Make It An Inevitable Tool For Such Oragaisation To Remain Competitive(Moberg, Cutler, Gross And Speh; 2002). The Need For Information Sharing Within Organisation And Among Organisations Which Offer Similar Services Has Been Highlighted To Be A Direct Step Toward Addressing Organisational Challenges. This Is Why Mohammed, Maroof, Ali And Huda (2015) Described Information Sharing As The Exchange Of Information Between Employees Within And Outside An Agency Or Providing Accessibility To Data And Information To Other Agencies In Order To Allow Efficient Decision Making. It Emerges As An Impetus To Solve Complex Issue In Service Delivery In Any Organization Such As Educational, Health, Commerce And Among Others. Information Sharing Is Therefore An Act Of Transferring Knowledge From One Person To Another Or Among Many People With The Intention Of Adding Value To Organisational Activities (Mitchell, 2008).

There Are Many Contexts To Which Information Sharing Can Take Place. One Of Such Context Is Hospital Environment Whose Personnel Are Broadly Classified Into Medical And Paramedical Staff. From The Health Care Management Perspective, It Is Vital To Harness And Facilitate Tacit Knowledge Sharing Among Clinical Teams, Particularly When They Are Not Always Physically Co-Located But Must Exchange Their Critical Experimental Knowledge (Abidi, Cheah, And Curran, 2005). Therefore, Information Sharing Among Health Workers Could Involve Exchange Of Ideas On Clinical Experiences, Skills Or Know-How On Quality Medical Diagnosis And Decisions.

There Are Number Of Media To Which Information Or Knowledge Could Be Shared Among Health Workers. One Of Such Media Is Social Medium. Social Media Are The Computer-Mediated Tools Which Allow People Or Organisations To Create Career Interest, Share Or Exchange Information, Ideas, Pictures/Video In Virtual Community Or Network (Baruah, 2012). Safko And Brake (2009) Considered Social Media As Activities, Practices, And Behaviours Among Communities Of People Who Gather Online To Share Information, Knowledge And Opinions Using Conversational Media.Baruah (2012) Further Described The Term Social Media As The Use Of Web-Based And Mobile Technologies That Are Adopted In Turning The 
Communication Into An Interactive Dialogue. Social Media Differ From Traditional Or Industrial Media In Terms Of Quality, Reach, Frequency, Usability, Immediacy And Permanence. It Operates In Dialogic Transmission System (Many Sources-Many Receivers) With The Changes Which Represent The Focus Of The Emerging Field Of Techno-Self Studies. It Creates An Online Community That Relies On User's Participation And Contribution (Waters, Burnett, Lamm And Lucas, 2009).

Abidi, Hussini, Sriraj, Thienthong And Finley (2009) Submitted That Social Web Paradigm Can Be Helpful For Tacit Information Sharing Through Interactive And Collaborative Technologies, Such As Social Networking And Online Discussion Fora, Where A Community Of Specialised Health Practitioners Can Share, Critique And Validate Their Collective Experiential Knowledge. In Achieving This Goal, Technologies That Support Free-Form Interaction In Form Of Real-Time Conversations, Conferencing, Writing And Networking Are Needed (Mitri, 2003). According To Gil-Garcia, Guler, Pardo And Burke (2010), Electronic Information Sharing Is A Complex Socio-Technical Phenomenon Which Is Covered Both In Technical And Social Aspects.

The Core Issue In The Social Media Is Its Users And The Connections Between Them; Therefore Social Media Are Primarily Organised Around Users (Boyd \& Ellison, 2007; Joinson, 2008). Moreover, Most Of The Healthcare Institutions Also Engaged In Social Networking While Promoting Adequate Healthcare Services. Osimo (2008) Argued That Social Web Technologies Are Effective Tools For Transferring Information Among Doctors. Social Media Serves As A Medium Of Information Sharing Through Its Immediacy To Healthy And Direct Relationship Between Health Workers And Their Patient/Client In An Online Environment. This Immediacy Offers The Care Givers The Ability To Be Present, To Communicate, To Influence And Retain A Strong Position Towards Health Care Delivery. In Addition To Using Social Media Platforms To Monitor Conversation About Clinical Diagnosis, Laboratory Testing And Medical Advices, Healthcare Givers Are Increasingly Reaching Out To Their Patient/Client Via The Social Web To Communicate Clinical And Medical Messages. However, A Cursory Look At The Literature Revealed That Quite A Number Of Factors Could Facilitate The Use Of Social Media For Health Care Service Delivery. One Of Such Factors Is The Way A User Perceive The Social Media.

Perception Connotes The Ability Of An Individual To View The Relevance Of Particular Information To His Or Her Needs. It Involves The Organisation, Identification, And Interpretation Of Sensory Information In Order To Represent And Understand The Environment (Schacter, 2011). It Involves The Perceived Benefits Of Action, Barriers To Action, And Self-Efficacy Elements Of The Behaviour-Specific Cognitions(Pender, Murdaugh And Parsons, 2002). Perceptions May Also Provide A Collective Sense Of The Issues That Affect Day-To-Day Lives Including Local Laws And Public Transit (Doran, Gokhale And Dagnino, 2013).

Despite All These Assertions, It Is Quite Intriguing That Limited Studies On The Use Of Social Media For Information Sharing Among Health Workers In Developing Countries Like Nigeria Have Been Carried Out. It Is Against This Backdrop That This Study Is Being Carried To Investigate The Influence Of Perception And Use Of Social Media By Health Workers For Information Sharing In General Hospitals In Ibadan, Nigeria.

\section{STATEMENT OF THE PROBLEM}

Preliminary Observation Have Indicated That There Is A Paradigm Shift In Information Sharing Mechanism Among Health Workers From Traditional Way To The Information And Communication Technology (ICT) Platforms Such As Social Media. However, In Spite Of Empirical Evidence From Literature Demonstrating Heavy Use Of Social Media Platforms By Many Health Care Professionals And Organisations, There Is Still Lack Of Understanding On How To Maximize The Benefits Related To Information Sharing Within The Clinical Context. This Perhaps Could Be Largely Attributed To Perception Of Health Workers To Information Sharing Through Social Media Platforms. Hence, The Need For This Study.

\section{OBJECTIVES OF THE STUDY}

The Main Objective Of The Study Is To Investigate The Perceptionand Use Of Social Media By Health Workers For Information Sharing In Two General Hospitals In Ibadan, Nigeria.

The Specific Objectives Are To:

i. Find Out The Health Workers' Perception Of The Use Of Social Media For Information Sharing In The General Hospitals,

ii. Find Out The Frequency Of Use Of Social Media For Information Sharing By Health Workers In The General Hospitals And,

iii. Examine The Influence Of Perception Of The Health Workers On Their Use Of Social Media For Information Sharing In The General Hospitals.

\section{Research Questions}

The Following Research Questions Are Raised To Guide The Study: 
1. What Is The Health Workers' Perception Of The Use Of Social Media For Information Sharing In The Selected General Hospitals?

2. What Is The Frequency Of Use Of Social Media For Information Sharing By Health Workers In The General Hospitals?

\section{HYPOTHESIS}

The Following Null Hypothesis Was Tested At 0.05 Level Of Significance:

Ho1: There Is No Significant Relationship Between The Health Workers' Perception And Their Use Of Social Media For Information Sharing In The General Hospitals.

\section{Literature Review}

Use Of Social Media For Information Sharing By Health Workers

A Broad Conceptual Definition Of Social Media Is The Online And Mobile Accessible Services That Enable Individuals To Connect, Collaborate, And Share With Others In Real Time (Ressler And Glazer, 2010). Social Media Is About The Ability To Easily Connect, Save, And Access Content Through Services That Enable Information Sharing And Collaboration With Others. Common Examples Include Facebook, Twitter, And Google+. Under This Broad Understanding, Social Media Can Be Used In Many Different Ways. A Prominent Example Of Social Media Is Facebook, A Service Focused On Social Networking By Allowing The User To Connect With Family And Friends. There Are A Growing Number Of Social Media Tools That Focus On Digital Services. Social Media Can Be Defined As "Collaborative Online Applications And Technologies Which Enable And Encourage Participation, Conversation, Openness, Creation And Socialization Amongst A Community Of Users" (Bowley, 2009).

The Use Of Social Media To Share Information Is Gradually Replacing The Traditional Media Outlets Such As Television, Newspaper, And Radio. Social Media Has Become A Catchphrase That Managers Across Several Domains Are Using To Actively Communicate With Their Customers In Order To Maintain A Competitive Edge (Sjöberg, 2010). While The Advantages Are Becoming Obvious, The Knowledge On How To Effectively Share Information On Social Media Sites Is Crucial In Order To Actively Engage The Target Audience. Research On Information Sharing Has Typically Focused On Collaborative Information Behaviour. The Use Of Social Media For Responding To Emergencies And Creating Situational Awareness Has Risen In Recent Years (Qu, Huang, Zhang And Zhang, 2011; Starbird And Palen, 2012). Research In Professional Settings By Sonnenwald And Pierce (2000) Highlighted The Complex Interplay Between Social Interactions. They Also Found That Interwoven Situational Awareness And Social Networks Were Important For Information Sharing And Task Completion. Many Aspects Of Recent Web Technologies Are Referred To As Social Media, Also Known As Social Web, Social Software, Social Computing, Social Networking, And Web 2.0 (Osimo, 2008; Quasthoff, Sack And Meinel, 2007).

Social Interaction Is Experiencing A New Dynamics With The Advent Of Social Media Technologies. People Are Able To Share Information Such As Updates About Their Experiences As It Happens, With Minimal Effort And Time. A Recent Study Reported That Individuals Share Information With Their Friends And The General Public To Maintain A Sense Of Connection, As Well As Build Social Capital (Erickson, 2011).Social Media Is Also Expanding Into Different Areas Related To Health. For Example, Patientslikeme (2014) Is A Newly Created Service That Allows Patients To Monitor Their Disease, Treatments, And SelfReported Experiences. The Social Component Allows Users To Share Information With Other Patients That Have The Same Medical Condition, As Well As With Health Researchers And Healthcare Providers. There Are A Growing Number Of Sites For Health And Healthcare Related Purposes, Such As Tracking Health Measures, Rating Healthcare Providers, And Hospital Services (Fox And Duggan, 2013).

Healthcare Information Sharing Is Dealt With From The Perspective Of Either Relationships With Patients And The Need For Sharing Of Information About The Patients' Condition With The Patient, Or Relationships With Partner Organisations In Health Care. Here The Issues Of Trust Opened, Data Protection, Privacy And Observance Of Legal Requirements Play A Larger Role, (Simon Et Al., 2009; Sensmeier And Halley, 2009; Gold Et Al., 2009).

According To Rafaeli And Raban (2005), Information Sharing Is Defined As The Act Of Providing A Helpful Answer To A Request For Information. Thus, Sharing Is Different From Plain Posting Of Information In 'Broadcast' Mode. Sharing Is Responsive, Variable And Subject To Attenuation By Various Environmental Influences. Information May Be Shared In Different Levels In Private And Public Spaces, At Work Or NonWork Settings, By People From Different Disciplines And Depending On The Content Requested. The Quality And Reliability Of The Information Shared, And Its Acceptance, Its Trust, And Willingness To Ask For It Are All Variable Too. As One Knowledge-Centered Activity, Information Sharing Is The Fundamental Means Through Which Employees Can Contribute To Knowledge Application, Innovation, And Ultimately The Competitive Advantage Of The Organisation (Jackson, Chuang, Harden, Jiang And Joseph, 2006). 
The Use Of Internet As A Communication Tool And As One Of The Principal Sources Of Medical Information Has Become Increasingly Popular Among Healthcare Professionals (Bennett, Casebeer, Zheng And Kristofco, 2006; Romano, Gesualdo, Pandolfi, Tozzi And Ugazio, 2012). Among The Internet Initiatives, Social Web Tools Such As Blogs, Wikis, And Social Networking Websites Have Also Become The Preferred Tool For Communication And Collaboration By Healthcare Professionals In Recent Years (Antheunis, Tates And Nieboer, 2013; Cooper Et Al., 2012). Health Professionals Need Updated Health Information From Credible Sources To Improve Their Knowledge And Provide Evidence Based Health Care Services. Various Types Of Medical Errors Have Occurred In Resource-Limited Countries Because Of Poor Knowledge And Experience Sharing Practices Among Health Professionals (Jackson Et Al., 2014). The Rapid Growth Of Social Media Has Fundamentally Changed And Revolutionized The Way People Manage Information About Their Personal And Professional Lives (Garner And O’Sullivan, 2010; Giffords, 2009).

\section{Types Of Social Media Tools For Information Sharing}

The Advent/Emergence Of Social Media Tools Has Changed The Way Knowledge Is Retrieved, Communicated And Shared Among Groups Of Individuals. Social Media Tools Enable Knowledge Management And Knowledge Sharing Practices By Facilitating Knowledge Creation, Sharing And Collaboration Among Knowledge Workers (Paroutis And Al Saleh, 2009). Many Of The Social Media Tools Are Built On Open Source And Could Therefore Be Easily Integrated In Order To Enhance Knowledge Sharing (Mckenzie And Van Winkelen, 2011). In Line With This, Muneja And Abungu (2012) Are Of The Opinion That, "Being Freely Open Source And Easy To Adopt The Tools Can Revolutionize Provision Of Services And Lead To Rapid Growth Of Knowledge Acquisition". Social Media Tools Are Therefore Suitable For Knowledge Sharing Practices Since It Allows And Facilitate Knowledge To Flow And Disseminated And To Improve The Extraction And Utilization Of Tacit Knowledge. White (2010) Adds That, Social Media Tools Are Used To Publish Explicit Knowledge (Papers, Blog Posts, Articles, Tweets), To Get Exposure, To Find Knowledge From A Global Community Of Experts And To Engage Others To Share Knowledge. Further, The Utilisation Of Social Media Tools Facilitates Knowledge Sharing Across Widely Dispersed Elements Within Institutions By Involving People Who Have Common Interests To Create And Share Knowledge (Levy, 2009). This Can Be Achieved By Allowing Easy And Instant Communication Among Employees (Adamovic, Potgieter And Mearns, 2012).This Study Mentions The Following Categories Of Social Media Tools Which Can Be Employed To Enhance Knowledge Sharing Within Healthcare Institutions:

Social Networking Sites Are Sites Which Contain Social Media Tools Such As Facebook And Myspace Which Are Used To Facilitate Communication, Chat And Sharing Of Ideas Among People. Social Networking Sites Provide A Way To Get And Stay In Touch With Friends, Family And Associates (Mohamood And Richardson, 2011). Social Network Sites Help Fulfill Communication Needs And Wants. It Is A Convenient Method Of Communication And Provides The Ability To Stay Connected With Friends And Family, But On The Users Own Rate And Time (Urista, Dong And Day, 2009). Healthcare Provider Can Manage Their Interactions Within Their Own Schedule By Choosing When They Want To Read And Respond. The Internet Communication Is A Solitary Activity Usually Done Alone. However, It Is Efficient Because It Is A One-To-Many Method Of Communication That Allows Users To Quickly Spread Information. Social Networking Tools Such As Facebook And Twitter Are Very Important Social Media Tools To Enhance Knowledge Sharing Through Providing The Communication And Sharing Of Information (Lwoga, 2013). Facebook Provide Users With The Ability To Personalise Profiles With Photos And Information Therefore To Communicate More Efficiently (Ayu And Abrizah, 2011). Twitter Allows Users To Share Information Including Their Thoughts With Everyone (Kim And Abbas, 2010).

Video And Audio Sharing Social Media Tools Such As Youtube And Podcasts Contain Audio And Video Contents Which Are Available On The Internet And That Can Be Automatically Delivered To A Personal Computer Or MP Player (Harinarayana And Raju 2010; Kim And Abbas, 2010). Podcasts Can Be Stored Within Healthcare Organisation To Support Health Workers To Share Knowledge Through Listening To Lectures, Various Conversations. Penzhorn (2013) Adds That, "Research Has Shown That Information Is Remembered Better If It Is Encoded Both Visually And Verbally". Video Sharing Applications Such As Youtube Can Be Linked To Library Catalogues Therefore Making It Easier For Health Workers As Well As Library Users To Retrieve Their Needed Information (Webb, 2007). Mahmood And Richardson (2011) Add That, Youtube Enhance Sharing Information Through Videos, To Conduct Interviews And To Upload Various Speeches.

Social Media Tools Such As Flickr Or Picasa Are Used To Enhance Photos And Image Sharing Within Community Of Interest (Penzhorn, 2013). Grosseck (2009) Adds That, Photo/Slide Sharing Can Be Used To Inspire Writing And Creativity, Create A Presentation Using The Photos And Use Tags To Find Photos Of Areas And Events Around The World. Therefore, Photo And Image Sharing Tools Can Enhance Knowledge Sharing Practices Whereby Health Workers Can Post A Picture With Information Which Needs To Be Shared 
And Others Can Tag And Provide Comments To That Picture. Photo And Image Sharing Is Among The Useful Tools To Enhance Information Sharing Because People Can Take Few Minutes To Respond As Compared To Reading An Article.

Blogs Are Regarded As The Central Focus For Discussion Forums Among Knowledge Workers (Hislop, 2013). Literature By Yu, Lu And Liu (2010) Emphasized The Use Of Blogs To Enhance Knowledge Transfer And Flow Within Organisations Hence To Encourage And Support Information Sharing. Weblogs Can Also Be Viewed As An Evolved Form Of Personal Web Pages Used To Publish Personal Knowledge. Blogs Provide Control To An Individual Or Group Of Individuals For Publishing Contents Or Making Commentary On It By Providing Quick Feedback (Grosseck, 2009; Kumar, 2009). Blogs Are Reported As Useful Knowledge Sharing Platforms For Within A Collaborative Work Environment (Chai And Kim, 2010).

Wikis Are Collaborative And Communication Space Which Provides Freedom, Ease Of Use And Access, And A Better Way To Organise Knowledge (Grace, 2009; Parker \& Chao, 2007). Wikis Provide Links And References To Other Web Sites That Are Related To Various Subjects In Order To Help Users To Better Understand The Context And Therefore, To Easily Add And Edit Information (Grace, 2009; Levy, 2009; Murugesan, 2007). Wikis Are Also Used To Facilitate Knowledge Sharing, Collaborative Authoring And Online Discussion (Kim And Abbas, 2011). According To Grace (2009), Researchers Can Easily Add Their Articles On Wikis And Allow Others To Read, Edit And Link To Additional Relevant Resources. Health Workers Can Use Wikis To Facilitate Communication, To Distribute Documents, To Collaborate And Share Knowledge (Grosseck, 2009; Kumar, 2009). Specific Health Care Considerations Relate To The Open Nature Of These Sites And Can Be Used To Disseminate Information More Easily To Patients.

Social Bookmarking Sites Are Very Important To Support Knowledge Sharing Practices Within Higher Learning Institutions (Gray And Thompson, 2008). Social Bookmarking Can Be Used To Link Academics To Free Bookmarking Sites Online And Present Many Opportunities For Networking With Other Persons Or Scholars With Similar Interests In Order For Them To Share Knowledge Easily (Akeriwa, Penzhorn And Holmner, 2014). Social Bookmarking Sites Allow Users To Build And Store Collections Of Chosen WebBased Resources Over Time In A Database That Is Automatically Maintained And Shared On A Web Site (Grosseck, 2009). The User Is Able To Assign His/Her Own Keywords Or "Tags" And Annotations (Such As Reviews) And May Be Able To Add Comments On Other People's Bookmarked Resources As Well (Gray And Thompson, 2008).

Really Simple Syndication (RSS) Feeds Is A Family Of Web Feed Formats Used For Syndicating Content From Blogs Or Web Pages Which Are Useful In Knowledge Creation And Sharing (Grosseck, 2009; Murugesan, 2007). RSS Feeds Is A Social Media Tool Which Contains An XML File That Summarizes Information Items And Links To The Information Sources, And Therefore, Informs Users Of Updates To Blogs Or Other Web Sites Which They Are Interested In Or Stored Within Their Institutions (Murugesan, 2007). Chua And Goh (2010) Add That, RSS Feeds Supports Information Dissemination Within Academic Libraries Whereby Users Can Be Kept Informed Of The Changes Made To The Web Content Including Blogs And Podcasts Without Having To Revisit The Website.

\section{Perception Of Health Workersto Information Sharing Through Social Media}

Human Understanding And The Resulting Organisational Behaviour Are Largely Based Upon How A Person Perceives And Think About Situation (Elsbach, Barr And Hargadon, 2005). Perceptions Matter Because How A Person Makes Sense Of A Situation Affects His Or Her Attitudes, Attributes And Behaviours. The Process Of Perceiving Involves Noticing, Selecting, And Organising Information In Order To Respond. Information Is Naturally Lost Or Distorted In This Complex Process, So The Knowledge Upon Each Person's Is Based May Be Incomplete Or Inaccurate. However, The Actor Assumes His Or Her Knowledge Is Complete, And Thus May Act Upon Deficient Information. People Vary Greatly In What They Notice And What Draws Their Focused Attention. Their Attention Processes Will Be Influenced And Filtered By Their Assumptions, Values, Knowledge, Goals, Past Experiences, And Other Personal Differences. As A Result They Will Only Take Part In The Result They Are Presented With, And Subsequently Act Upon Partial Information.

In Addition, The Partial Information That Is Taken In Is Subject To Other Mental Processes That Can Create Further Distortions. Social Support Has Been Previously Recognized As A Significant Predictor Of Physical Health (Hale, Hannum And Espelage, 2005). Thus, One Aspect That Public Health Workers May Capitalise On Is Social Support, Where Members Of The Community Share Advice, Suggestions And Information(Rimer And Glanz, 2005), And Make Comparative Self-Appraisals In The Process. These May Be Attained Through Public Health Social Work Efforts That Target Changes In The Surrounding Community, Social, And Physical Environments In Addition To Individually Based Approaches To Changing Perceptions Of The Health Risks Of Certain Health Behaviors. Therefore, Systems For Managing Knowledge And Sharing Expertise Must Recognize The Perceived Value Of Forming A Perception Of The Credibility Of Individual Pieces Of Knowledge (Hertzum, 2002). 
The Rapid Growth Of Social Media Has Fundamentally Changed And Revolutionised The Way People Manage Information About Their Personal And Professional Lives (Garner And O'Sullivan, 2010; Giffords, 2009). There Has Been A Substantial Increase In The Use Of Internet Communication Using Social Media, Including Blogs, And An Increase In The Number Of Social Networking Sites Available For Use. There Is Increasing Literature On The Potential For Ethical Dilemmas For Health Workers Who Use Blogs And Social Media Sites (Duncan-Daston, Hunter-Sloan And Fullmer, 2013; Giffords, 2009; Kays, 2011; Judd And Johnston, 2012; Nye, 2011; Young, 2009), Psychologists (Lehavot, Barnett, Smith, And Zickuhr, 2010; Tunick, Mednick And Conroy, 2011), Medical Doctors (Brown, 2010; Garner And Osullivan, 2010; Macdonald, Sohn And Ellis, 2010), Nurses (Halle, 2012; Thompson, 2012), And Other Professionals Such As Psychiatrists (Luo, 2009).

According To Newbold And Campos (2011) Healthcare Facilities Are Taking Advantage Of The Reach Provided By Social Media To Publish Health Information And To Engage With Their Customers. Social Media Now Seem To Have Replaced Face To Face Contact As A Means Of Communication Between People (Crawford, 2009). The Mayo Clinic, For Example, Is One Such Pioneering Healthcare Facility That Has Used Social Media To Allow Patients To Interact With One Another And With Health Professionals To Seek Health Information (Newbold And Campos, 2011).

The Explosion Of Social Networking Sites Has Changed The Way People Connect With And Share Information Amongst Themselves (Parrish, 2010). This Means That Health Workers Are Individually Responsible For Maintaining Careful Awareness Of Possible Ethical Dilemmas When Participating In Social Media (Kays, 2010). The Norms For The Profession Of Healthcare Are To Strive To Provide Services In An Objective, Impartial, And Respectful Manner, Ensuring That Clients' Interests Are First (Code Of Ethics CASW, 2005).

\section{METHODOLOGY}

Descriptive Survey Research Design Of Correlational Type Was Adopted For This Study. The Population Of The Study Consists Of Health Workers In General Hospitals In Ibadan And They Include; Adeoyo State Hospital, Yemetu, Jericho Nursing Home, Jericho,Adeoyo Hospital Ring Road And Oni And Sons, Ring Road. There Were Five Hundred And Forty One Health Workers In General Hospitals In Ibadan Out Of Which Three Hundred And Twenty Were Randomly Selected For The Study. Out Of The Three Hundred And Twenty Copies Of The Questionnaire Administered, Three Hundred And Were Retrieved And Found Usable For The Study. This Amounted To 94.0\% Response Rate.

\section{INSTRUMENT}

A Structured Questionnaire Titled, Research Questionnaire For Health Workers Was Used For The Collection Of Data. The Questionnaire Consists Of 31 Items Divided Into Three Sections, A To C. Section A Elicits The Demographic Information Of The Respondents Which Include; Name Of Hospital, Age, Gender, Marital Status And Profession.Section B Elicits The Perception Of Health Workers To The Use Of Social Media For Information Sharing. The Scale Was Adapted From Sharma (2013). It Comprises 10 Items On A Four-Point Likert Scale Of Strongly Agree=4, Agree=3, Disagree=2, Strongly Disagree=1. Section C Elicits The Frequency Of Use Of Social Media By Health Workers For Informationsharing. It Is A Modified Form Of The Scale By Panahi Et Al., (2012). It Contains 16 Items On A Five-Point Scale Of Daily=5, Weekly=4, Monthly=3, Occasionally=2, Rarely=1.In Order To Ensure The Face Validity Of The Instrument, The Questionnaire Was Subjected To Scrutiny And Correction Byexperts In The Field After Which Necessary Amendment Was Incorporated. Further, The Reliability Of The Instrument Was Determined Through A Pretest Method Which Showed That For Perception 0.89 While Frequency Of Use Of Social Media By Health Workers Recorded A Scale Of 0.81.Data Collected Wereanalysed Using Descriptive And Inferential Statistics. Descriptive Statistics Such As Frequencies And Percentages, Mean And Standard Deviation Were Used To Analysethe Research Questions 1 And 2 While Pearson Product Moment Correlation Was Used To Analyse The Hypothesisin Order To Establish The Relationship Between The Variables.

\section{Research Question 1}

VII. RESULTS

Research Question 1: What Is The Health Workers' Perception Of The Use Of Social Media For Information Sharing In The Selected General Hospitals?Research Question One Sought To Determine Respondents' Perception To The Use Of Social Media For Information Sharing. In Order To Achieve This, Respondents Were Asked To Respond To Items Relating To Their Perception On The Use Of Social Media For Information Sharing And The Result Is Presented In Table 1 
Table 1: Perception Of Health Workers To The Use Of Social Media For Information Sharing

\begin{tabular}{|c|c|c|c|c|c|c|c|c|c|c|c|}
\hline \multirow{2}{*}{$\begin{array}{l}\mathbf{S} \\
/ \\
\mathbf{N}\end{array}$} & \multirow[b]{2}{*}{ PERCEPTION } & \multicolumn{2}{|c|}{$\mathbf{S A}$} & \multicolumn{2}{|c|}{$\mathbf{A}$} & \multicolumn{2}{|c|}{ D } & \multicolumn{2}{|c|}{ SD } & \multirow[b]{2}{*}{ Mean } & \multirow[b]{2}{*}{ STD } \\
\hline & & $\mathbf{N}$ & $\%$ & $\mathbf{N}$ & $\%$ & $\mathbf{N}$ & $\%$ & $\mathbf{N}$ & $\%$ & & \\
\hline I. & $\begin{array}{l}\text { Information Sharing Through Social } \\
\text { Media Has Shared Value }\end{array}$ & 258 & 85.7 & 42 & 14.0 & 1 & .3 & 0 & 0.0 & 3.8538 & .36317 \\
\hline $\mathrm{Ii}$ & $\begin{array}{l}\text { Information Sharing Through Social } \\
\text { Media Is Cost Effective }\end{array}$ & 227 & 75.4 & 58 & 19.3 & 10 & 3.3 & 6 & 2.0 & 3.6811 & 63609 \\
\hline $\begin{array}{l}\text { Ii } \\
\text { i. }\end{array}$ & $\begin{array}{l}\text { Information Sharing Through Social } \\
\text { Media Improves The Quality Of } \\
\text { Care }\end{array}$ & 60 & 19.9 & $\begin{array}{r}13 \\
0\end{array}$ & 43.2 & $\begin{array}{r}10 \\
7\end{array}$ & 35.5 & 4 & 1.3 & 2.8173 & .75928 \\
\hline $\begin{array}{l}\mathrm{I} \\
\mathrm{v}\end{array}$ & $\begin{array}{l}\text { Information Sharing Through Social } \\
\text { Media Reduces Competitiveness } \\
\text { Among Peers }\end{array}$ & 24 & 8.0 & $\begin{array}{r}10 \\
3\end{array}$ & 34.2 & $\begin{array}{r}16 \\
7\end{array}$ & 55.5 & 7 & 2.3 & 2.4784 & .67604 \\
\hline $\mathrm{V}$ & $\begin{array}{l}\text { Information Sharing Through Social } \\
\text { Media Improves Communication } \\
\text { Among Health Professionals }\end{array}$ & 121 & 40.2 & $\begin{array}{r}17 \\
6\end{array}$ & 58.5 & 2 & .7 & 2 & .7 & 3.3821 & .53871 \\
\hline $\begin{array}{l}\text { V } \\
\text { i. }\end{array}$ & $\begin{array}{l}\text { Information Sharing Through Social } \\
\text { Media Will Make Positive Changes } \\
\text { In The Hospital }\end{array}$ & 36 & 12.0 & $\begin{array}{r}25 \\
6\end{array}$ & 85.0 & 6 & 2.0 & 3 & 1.0 & 3.0797 & .41668 \\
\hline $\begin{array}{l}\text { V } \\
\text { ii }\end{array}$ & $\begin{array}{l}\text { Information Sharing Through Social } \\
\text { Media Reduces Medical Error }\end{array}$ & 73 & 24.3 & $\begin{array}{r}15 \\
7\end{array}$ & 52.2 & 66 & 21.9 & 5 & 1.7 & 2.9900 & .72794 \\
\hline $\begin{array}{l}\text { V } \\
\text { ii } \\
\text { i. }\end{array}$ & $\begin{array}{l}\text { Information Sharing Through Social } \\
\text { Media Is Not Time Consuming }\end{array}$ & 72 & 23.9 & $\begin{array}{r}19 \\
9\end{array}$ & 66.1 & 13 & 4.3 & 17 & 5.6 & 3.0831 & .70928 \\
\hline $\begin{array}{l}\mathrm{I} \\
\mathrm{x}\end{array}$ & $\begin{array}{l}\text { Information Sharing Through Social } \\
\text { Media Must Be Encouraged }\end{array}$ & 65 & 21.6 & $\begin{array}{r}23 \\
4\end{array}$ & 77.7 & 2 & .7 & 0 & 0.0 & 3.2093 & .42353 \\
\hline $\mathrm{X}$ & $\begin{array}{l}\text { Information Sharing Through Social } \\
\text { Media Is Not Seems To Be An } \\
\text { Additional Responsibility }\end{array}$ & 78 & 25.9 & $\begin{array}{r}17 \\
6\end{array}$ & 58.5 & 38 & 12.6 & 9 & 3.0 & 3.0731 & .70803 \\
\hline & Grand Mean & & 31.6 & & & SD & & 5.958 & & & \\
\hline
\end{tabular}

Given The Number Of Items In Table 1, The Highest Possible Score Is 40 (I.E 4 X $10=40$ ) Test. Assuming That The Score Range Of 1-13 = Low Perception, 14- 26 = Moderate Perception And 27- 40 Indicates High Perception. It Could Be Observed From The Table That The Weighted Mean Score Is 31.65 And With Standard Deviation Of 5.96 Which Falls Within The High Range. This Implies That The Health Workers' Perception To Information Sharing To The Use Of Social Media Is High. The Implication Of This Is That Health Workers Generally Agree That Social Media Is A Means Of Information Sharing.

Research Question 2: What Is The Frequency Of Use Of Social Media For Information Sharing By Health Workers In The General Hospitals?Research Question Two Sought To Find Out The Frequency Of Use Of Social Media For Information Sharing Among Health Workers In General Hospitals In Ibadan And The Result Is Presented In Table 2.

Table 2: Frequency Of Use Of Social Media For Information Sharing Among Health Workers

\begin{tabular}{|c|c|c|c|c|c|c|c|c|c|c|c|c|c|}
\hline \multirow[b]{3}{*}{$\mathrm{S} / \mathrm{N}$} & \multirow{2}{*}{$\begin{array}{l}\text { SOCIAL } \\
\text { MEDIA }\end{array}$} & \multicolumn{2}{|c|}{ Daily } & \multicolumn{2}{|l|}{ Weekk } & \multicolumn{2}{|l|}{ Monthly } & \multicolumn{2}{|c|}{ Occasionally } & \multicolumn{2}{|c|}{ Rarely } & \multirow[t]{2}{*}{ Mean } & \multirow[t]{2}{*}{ STD } \\
\hline & & $\mathbf{N}$ & $\%$ & $\mathbf{N}$ & $\%$ & $\mathbf{N}$ & $\%$ & $\mathbf{N}$ & $\%$ & $\mathbf{N}$ & $\%$ & & \\
\hline & \multicolumn{11}{|c|}{ SOCIAL NETWORKING SITES } & & \\
\hline I. & Facebook & 172 & 57.1 & 29 & 9.6 & 6 & 2.0 & 61 & 20.3 & 33 & 11.0 & 3.8173 & 1.53726 \\
\hline Ii. & Googlet & 35 & 11.6 & 15 & 5.0 & 62 & 20.6 & 87 & 28.9 & 102 & 33.9 & 2.3156 & 1.30258 \\
\hline Iii. & Myspace & 1 & $\frac{1}{3}$ & 3 & 1.0 & 5 & 1.7 & 119 & 39.5 & 173 & 57.5 & 1.4718 & 0.61917 \\
\hline Iv. & Twitter & 8 & 2.7 & 8 & 2.7 & 19 & 6.3 & 187 & 62.1 & 79 & 26.2 & 1.9336 & 0.81787 \\
\hline \multirow[t]{3}{*}{ V. } & Whatsapp & 261 & 86.7 & 31 & 10.3 & 2 & .7 & 4 & 1.3 & 3 & 1.0 & 4.8040 & 0.60947 \\
\hline & & & & & & & & & & & & 14.3423 & 4.88635 \\
\hline & \multicolumn{13}{|c|}{ MEDIA SHARING SITES } \\
\hline Vi. & Youtube & 51 & 16.9 & 35 & 11.6 & 62 & 20.6 & 120 & 39.9 & 33 & 11.0 & 2.8372 & 1.26889 \\
\hline Vii. & Flickr & - & - & 3 & 1.0 & 8 & 2.7 & 116 & 38.5 & 174 & 57.8 & 1.4684 & 0.60263 \\
\hline Viiii. & Slideshare & 21 & 7.0 & 55 & 18.3 & 20 & 6.6 & 89 & 29.6 & 116 & 38.5 & 2.2558 & 1.32326 \\
\hline Ix. & Instagram & 29 & 9.6 & 18 & 6.0 & 75 & 24.9 & 41 & 13.6 & 138 & 45.8 & 2.1993 & 1.33422 \\
\hline \multirow[t]{3}{*}{$\mathrm{X}}$. & Pinterest & 1 & 3 & 5 & 1.7 & 55 & 18.3 & 14 & 4.7 & 226 & 75.1 & 1.4751 & 0.86999 \\
\hline & & & & & & & & & & & & 10.235 & 5.39899 \\
\hline & BLOGS & & & & & & & & & & & & \\
\hline $\mathrm{Xi}$ & Linkedin & 2 & .7 & 6 & 2.0 & 12 & 4.0 & 123 & 40.9 & 158 & 52.5 & 1.5748 & 0.72473 \\
\hline Xii. & Tumblr & 0 & 0.0 & 2 & .7 & 57 & 18.9 & 7 & 2.3 & 235 & 78.1 & 1.4219 & 0.81530 \\
\hline \multirow[t]{3}{*}{ Xiii. } & $\begin{array}{l}\text { Patientlike } \\
\text { me }\end{array}$ & 0 & 0.0 & 6 & 2.0 & 57 & 18.9 & 9 & 3.0 & 229 & 76.1 & 1.4684 & 0.86593 \\
\hline & & & & & & & & & & & & 4.4651 & 2.40596 \\
\hline & RSSFEED & & & & & & & & & & & & \\
\hline Xiv. & Goggle & 62 & 20.6 & 5 & 1.7 & 8 & 2.7 & 77 & 25.6 & 149 & 49.5 & 2.1827 & 1.55451 \\
\hline
\end{tabular}


Shows That The Social Media Platform Mainly Used By Health Workers For Information Sharing Is The Whatsapp Which Ranked Highest In Terms Of Frequency Of Usage With The Mean Score Of 4.804 This Is Followed By Facebook With A Mean Score Of 3.8173 Which Ranked Second In Terms Of Frequency Of Usage For Information Sharing While Wikipedia Ranked Third With A Mean Score Of 3.3289. However, The Least Platform For Information Sharing Among Health Workers In Ibadan General Hospitals Was Flickr With Mean Score Of 1.4684 And Standard Deviation Of 0.60263. A Further Observation Of The Table Reveals That Social Networking Sites Were The Platforms Most Frequently Used By Respondents For Information Sharing While Media Sharing Sites Such As Youtube, Flickr, Instagram Were Either Rarely Used Or Occasionally Used As Majority Of Respondents Have Indicated (For Example About 75\% Rarely Use Pinterest While 57.8 Rarely Use Flickr For Information Sharing). Only A Few Respondents 20.6\% And 1.3\% Make Use Of Google Reader And Feed Reader Respectively For Information Sharing. Inference Could Therefore Be Drawn From The Table That The Most Frequently Used Social Media For Information Sharing Among Health Workers In General Hospitals In Ibadanare The Social Networking Sites Such As Whatsapp, Facebook And Google+. This Could Be Due To The Fact That These Are The Commonly Used Platform And That It Has Mobile Device Application.

\section{Hypothesis One}

The Hypothesis Which Stated That 'There Is No Significant Relationship Between The Health Workers' Perception And Their Use Of Social Media For Information Sharing In The General Hospitalswas Analysed Using Pearson Correlation To Test The Relationship And The Result Is Presented In Table 3.

Table 3: Table Of Correlation Showing Relationship Between Perception And Information Sharing Through Social Media

\begin{tabular}{|l|l|l|l|l|l|l|l|}
\hline & N & X & SD & Df & R & P & \\
\hline $\begin{array}{l}\text { Health Worker's } \\
\text { Perception }\end{array}$ & 301 & 31.6479 & 5.95875 & & & \\
\cline { 1 - 3 } $\begin{array}{l}\text { Information Sharing } \\
\text { Through Social } \\
\text { Media }\end{array}$ & 301 & 44.79 & 8.34 & 298 & -3.74 & 0.19 & N.S \\
\hline
\end{tabular}

Table 3 Shows That The Relationship Between Health Workers' Perception And Information Sharing Through Social Media Is Negative And Not Statistically Significant $(\mathrm{P}>0.05)$. The Null Hypothesis That 'There Is No Significant Relationship Between The Health Workers' Perception And Their Use Of Social Media For Information Sharing In The General Hospitalswas Therefore Accepted. This Implies That There Is No Significant Relationship Between The Health Workers' Perception And Their Use Of Social Media For Information Sharing In The General Hospitals. The Implication Of This Result Is That The Fact That There Is A Positive Perception On The Use Of Social Media For Information Sharing Does Not Translate To Actual Information Sharing Through Social Media.

\section{DISCUSSION OF FINDINGS}

The Result Of Research Question One Revealed That The Health Workers' Perception To Information Sharing To The Use Of Social Media Is High. The Implication Of This Is That Health Workers Generally Agrees That Social Media Is A Means Of Information Sharing. This Is In Agreement With The Position Of Garner\& O'Sullivan, (2010) As Well As That Of Giffords (2009) Who Submitted That The Rapid Growth Of Social Media Has Fundamentally Changed And Revolutionized The Way People Manage Information About Their Personal And Professional Lives. The Result Further Lends Credence To The Findings Of Pew Research Center (2006) That Social Media Has Been Widely Accepted As A Means Of Information Sharing While Remus \& Kennedy (2012) Submitted That Health Workers Are Increasingly Expected To Develop Competencies In Informatics. Thus, Information Communication Technology Has Become A Regular Part Of Daily Life, Both At Work And At Home. This Is True For Health Professionals, Where The Application Of Technology Is An Integral Part Of The Profession. Accurate Health Information Is Important For Individuals And Communities As They Make Decisions For Their Personal And Collective Health And This Is Why Health Workers' Perception To Information Sharing Through Social Media Is High Among Health Workers In Government Hospitals In Ibadan.

The Result Of Research Question Two Revealed That The Social Media Platform Mainly Used By Health Workers For Information Sharing Is The Whatsapp Which Ranked Highest In Terms Of Frequency With Majority Of The Respondents Claiming To Use This Platform Daily For Information Sharing. This Is Followed By Facebook And Wikipedia Respectively. All These Are Social Networking Sites. The Implication Of This Finding Is That Social Networking Sites Are The Mostly Used Social Media For Information Sharing Among Health Workers In Government Hospitals In Ibadan. This Is Because Social Networking Sites Are Sites Which 
Contain Social Media Tools Such As Facebook And Myspace Which Are Used To Facilitate Communication, Chat And Sharing Of Ideas Among People (Boyd And Ellison 2008). This Result Supports Mohamood\& Richardson, (2011) That Social Networking Sites Provide A Way To Get And Stay In Touch With Friends, Family And Associates. It Further Corroborates Lwoga, (2013) That Social Networking Tools Such As Facebook And Twitter Are Very Important Social Media Tools To Enhance Knowledge Sharing Through Providing The Communication And Sharing Of Information. Facebook Provide Users With The Ability To Personalise Profiles With Photos And Information Therefore To Communicate More Efficiently (Ayu\&Abrizah, 2011). Twitter Allows Users To Share Information Including Their Thoughts With Everyone (Kim \& Abbas, 2010).

The Result Further Revealed That Media Sharing Sites Such As Youtube, Flickr, Instagram Were Either Rarely Used Or Occasionally Used As Majority Of Respondents Have Indicated (For Example About 75\% Rarely Use Pinterest While 57.8 Rarely Use Flickr For Information Sharing). The Result Of Hypothesis One Showed That There Is No Significant Relationship Between The Health Workers' Perception And Their Use Of Social Media For Information Sharing In The General Hospitals. The Implication Of This Result Is That The Fact That There Is A Positive Perception On The Use Of Social Media For Information Sharing Does Not Translate To Actual Information Sharing Through Social Media. The Finding Seems Not To Agree With Elsbach, Barr, \&Hargadon (2005) That Human Understanding And The Resulting Organisational Behaviour Are Largely Based Upon How A Person Perceives And Think About Situation. In Addition, Zulman Et Al., (2011) Finds That Individuals' Preferences About Information Sharing Depend On The Type Of Information Being Shared, Who The Information Is Being Shared With And What Role The Individual Receiving The Information Plays In The Care Or Treatment Of The Individual With Life Experience. Therefore, Systems For Managing Knowledge And Sharing Expertise Must Recognise The Perceived Value Of Forming A Perception Of The Credibility Of Individual Pieces Of Knowledge (Hertzum, 2002). Previous Researchers Have Found Ethical Dilemmas For Health Workers Who Use Blogs And Social Media Sites (Duncan-Daston, Hunter-Sloan \&Fullmer, 2013; Giffords, 2009; Kays, 2011; Judd \& Johnston, 2012; Nye, 2011; Young, 2009), Psychologists (Lehavot, Barnett, Smith, \&Zickuhr, 2010; Tunick, Mednick, \& Conroy, 2011), Medical Doctors (Brown, 2010; Garner \&Osullivan, 2010; Macdonald, Sohn, \& Ellis, 2010), Nurses (Halle, 2012; Thompson, 2012), And Other Professionals Such As Psychiatrists (Luo, 2009).

\section{CONCLUSION}

The Study Established That Social Media Provides Opportunity For Health Workers To Join A Support Group In Order To Share Experiences, Collaborate And Interact For Learning And Treatment Purposes. Social Media As A Virtual Community Enhances Communications By Creating A Comfortable Environment For Engaging And Exchanging Information. In Other Word, When Health Care Givers Are Faced With Health Decision, Social Media Can Provide A New Avenue Of Health Related Information And Dialogue. Some May Share A Health Goal To Generate Support Or Engage In Patient Community To Interact With Other Health Care Professionals.

\section{RECOMMENDATIONS}

The Following Recommendations Were Made Based On The Findings Of The Study:

1. Specific Professional Social Media Platform Should Be Created For The Health Care Practitioners In The General Hospitals. This Will Further Influence Their Positive Perception To The Use Of Social Media For Information Sharing.

2. Health Workers Intending To Use Social Media Must Ensure That Professional Interactions Between/Among Other Health Care Professionals, Including The Transmission Of Any Health Data, Satisfy The Local Policy Or Legislation.

3. Health Workers Using Social Media Should Promote Its Use For Sharing Health Research Information.

\section{REFERENCES}

[1] Abidi, S.S.R., Hussini, S., Sriraj, W., Thienthong, S. And Finley, A. 2009. Knowledge Sharing For Paediatric Pain Management Via A Web 2.0 Framework. Studies Inhealth Technology And Management. 150: 287-291.

[2] Acquisti, A. And Gross, R. 2006. Imagined Communities: Awareness, Information Sharing, And Privacy On The Facebook Privacy Enhancing Technologies Workshop Http://Heinz.Cmu.Edu/ Acquisti/Papers/Acquisti-Grossfacebook- Privacy-PET-Final.Pdf

[3] Adamovic, D., Potgieter, A. And Mearns, M. 2012. Knowledge Sharing Through Social Media: Investigating Trends And Technologies In A Global Marketing And Advertising Research Company. South Africa Journal Of Information Management, 14.1: 1-7. 
[4] Akeriwa, M., Penzhorn, C. And Holmer, M. 2014. Using Mobile Technologies For Social Media Based Library Services At The University Of Development Studies Library, Ghana. Information Development, $1-10$.

[5] Antheunis, M. L., Tates, K. And Nieboer, T. E. 2013. Patients' And Health Professionals' Use Of Social Media In Health Care: Motives, Barriers And Expectations. Patient Education And Counseling 92.3: 426

[6] Archibald, M. M. And Clark, A. M. 2014. Twitter And Nursing Research: How Diffusion Of Innovation Theory Can Help Uptake. Journal Of Advanced Nursing, 70.3: 3-5.

[7] Barak, A., And Grohol, J. M. 2011.Current And Future Trends In Internet-Supported Mental Health Interventions.Jouma/ Of Technology In Human Services, 29: 155-196.

[8] Barton, A. J. 2011. Using Social Media As An Institutional Resource: Implications For The Clinical Nurse Specialist. Clinical Nurse Specialist, 25.3: 107-9.

[9] Barua, A., Ravindran, S. And Whinston, A. B. 2007.Enabling Information Sharing Within Organisations. Information Technology And Management, 81: 31-45. Retrieved April 9, 2016, From Http://Ariel1.Xu.Edu:2083/Ejc/Pdf.Cgi/Barua_Anitesh.Pdf

[10] Bassell, K. 2010. Social Media And The Implications For Nursing Faculty Mentoring: A Review Of The Literature. Teaching And Learning In Nursing, 5.4: 143-148.

[11] Bennett, N.L., Casebeer, L.L., Zheng, S. And Kristofco. R. J. 2006. Contineduc Health Prof. Spring; 26.2: 120-7. Outcomes, Inc., Birmingham, Alabama, USA.

[12] Boyd, D.M. And Ellison, N.B. 2008. Social Network Sites: Definition, History And Scholarship. Journal Of Computer-Mediated Communication, 13:210-230.

[13] Brown, A. D. 2010. Social Media: A New Frontier In Reflective Practice. Medical Education, 44: $744-$ 745.

[14] Chua, A.Y.K. And Goh, D.H. 2010. A Study Of Web 2.0 Applications In Library Websites.Library And Information Science, 32 (3): 203-211.

[15] Cockrell, C. 2007. Quality And Quantity Of Motivation In Functional And Dysfunctional Knowledge Sharing. Unpublished Doctoral Dissertation, University Of Kentucky, Lexington, KY, USA

[16] Collins, C. J. And Smith, K. G. 2006. Knowledge Exchange And Combination: The Role Of Human Resource Practices In The Performance Of High-Technology Firms.

[17] Cooper, C. P., Gelb, C. A., Rim, S. H., Hawkins, N. A., Rodriguez, J. L. And Polonec, L. 2012. Physicians Who Use Social Media And Other Internet-Based Communication Technologies, Journal Of The American Medical Informatics Association.

[18] Dantas, A. And Seville, E. 2006. Organizational Issues In Implementing An Information Sharing Framework: Lessons From The Matata Flooding Events In New Zealand. Journal Of Contingencies And Crisis Management, 14.1: 38-52.

[19] Denecke K, Nejdl W. 2009. How Valuable Is Medical Social Media Data? Content Analysis Of The Medical Web. Inform Sci.179.12: 1870-80.

[20] Doran, D., Gokhale, S. And Dagnino, A. 2013.Understanding Common Perceptions From Online Social Media, In Proc. Of Intl. Conference On Software Engineering And Knowledge Engineering, 107-112.

[21] Gefen, D. 2002. Reflections On The Dimensions Of Trust And Trustworthiness Among Online Consumers.Database For Advances In Information Systems, 33.3: 38-53.

[22] Gefen, D., Karahanna, E. And Straub, D.W. 2003. Trust And TAM In Online Shopping: An Integrated Model. MIS Quarterly, 27.1: 5190.

[23] Gibelman, M. 2005. What Social Workers Do (2 ${ }^{\text {nd }}$ ed.). Washington, DC. NASW Press

[24] Giffords, E. D. (2009). The Internet And Social Work: The Next Generation. Families In Society: The Journal Of Contemporary Social Services, 90.4: 413-418.

[25] Gil-Garcia, J. R., Guler, A., Pardo, T. A. And Burke, G. B. 2010.Trust In Government Cross-Boundary Information Sharing Initiatives: Identifying The Determinants. In 43rd Hawaii International Conference On Systemsciences, 1-10.

[26] Gold, M., Philip, J. Mclver, S. And Komesaroff, P.A. (2009). Between A Rock And A Hard Place: Exploring The Conflict Between Respecting The Privacy Of Patients And Informing Their Carers. Internal Medicine Journal, 39.9: 582-587.

[27] Hale, C.J., Hannum, J.W., And Espelage, D.L. 2005. Social Support And Physical Health: The Importance Of Belonging. Journal Of American College Health, 53: 276-284.

[28] Halle, B. 2012. A Code For Nurses: Professional And Social Media Ethics In Action. Arizona Nurse, Retrieved 22/02/2016 From Http://Find.Galegroup.Com.Libproxy.Uregina.Ca:2048/Gtx/Infomark.Do?\&Source=Gale \&Srcprod=EAI M\&Prodid=EAIM \&Usergroupname=Ureginalib $\&$ Tabid=T003\&Docid=A316664374 $\&$ Type $=$ Retrieve $\&$ Contentset $=$ IAC-Documents $\&$ Version $=1.0$ 
[29] Hansen, M. T. 2002. Knowledge Network: Explaining Effective Knowledge Sharing In Multiunit Companies. Organization Science, 13.3: 232-248.

[30] Harinarayana, N.S. And Raju, N.V. 2010. Web 2.0 Features In University Library Web Sites. The Electronic Library, 28.1: 69-88.

[31] Haythornthwaite, C. 1996. Social Network Analysis: An Approach And Technique For The Study Of Information Exchange. Library And Information Science Research, 18.4: 323-342.

[32] Health Canada. 2004. First Minister's Meeting On The Future Of Health Care. Retrieved From Www.HcSc.Gc.Ca/Hcs-Sss/Delivery-Prestation/Fptcollab/2004-Fmm-Rpm/Index-Eng.Php

[33] Hsia, T.L., Lin, L.M., Wu, J.H. And Tsai, H. T. 2010.A Framework For Designing Nursing Knowledge Management Systems.Interdisciplinary Journal Of Information, Knowledge \& Management, 1: 13-22. Retrieved From Http://Www.Ijikm.Org/Volume1/Ijikmv1p013-022 Hsia02.PdfHttp://Www.Usatoday.Com/News/Health/2004-10-12-Mind-Body-X.Htm

[34] Jackson, S. E., Chuang, C. H., Harden, E. E., Jiang, Y. And Joseph, J. M. 2006.Toward Developing Human Resource Management Systems For Knowledge-Intensive Teamwork. In J. M. Joseph (Ed.), Research In Personnel And Human Resources Management, 25: 27-70. Amsterdam: JAI.

[35] Jeon, S., Kim, Y. G., And Koh, J. 2011.An Integrative Model For Knowledge Sharing In CommunitiesOf-Practice.Journal Of Knowledge Management, 15.2: 251-269.

[36] Jewels, T., Underwood, A. And Depablos, C. 2008.The Role Of Informal Networks And Knowledge Sharing.Proceedings Of The 11th European Conference On Information Systems, Naples, Italy.

[37] Kim, Y.M. And Abbas, J. 2010. Adoption Of Library 2.0 Functionalities By Academic Libraries And Users: A Knowledge Management Perspective. The Journal Of Academic Librarianship, 36.3: 211-218.

[38] Krogh, G. And Hippel, E. 2002.Exploring The Open Source Software Phenomenon: Issues For Organization Science.

[39] Kumar, M. 2009. Academic Libraries In Electronic Environment: Paradigm Shift. Online, Available From: Http://Crl.Du.Ac.In/Ical09/Papers/Index_Files/Ical-16_182_384_3_RV.Pdf Accessed: 2014-04-08.

[40] Kumaraguru, P. And Cranor, L. F. 2005 Privacy Indexes: A Survey Of Westin's Studies, Technical Report CMU-ISRI-5-138, Carnegie Mellon University

[41] Lamberk, K. M., Barry, P. And Stoks, G. 2012. Risk Management And Legal Issues To The Use Of Social Media In The Health Care Setting.Journal Of Health C Risk Management, 31.4: 41-47.

[42] Lampe, C., Ellison, B., And Steinfield, C. 2008. Changes In Use And Perception Of Facebook.Proceedings Of The 2008 ACM Conference On Computer Supported Cooperative Work 721730. New York: ACM.

[43] Legare, F., Ratte, S., Gravel, K. And Graham, I. D. 2008. Barriers And Facilitators To Implementing Shared Decision-Making In Clinical Practice: Update Of A Systematic Review Of Health Professionals' Perceptions. 4th International Conference On Shared Decision Making, 73.3: 526-535

[44] Leiker, M. 2011.When To Friend A Patient: Social Media Tips For Health Care Professionals. WMJ. 110.1: 42-3.

[45] Levy, M. 2009. Web 2.0 Implications On Knowledge Management. Journal Of Knowledge Management, 13.1: $120-134$.

[46] Li, S., And Lin, B. 2006. Accessing Information Sharing And Information Quality In Supply Chain Management. Decision Support Systems, 42.3: 1641-1656.

[47] Liao. C., Pui-Lai, T. P., Liu, C., Kuo, P. And Chuang, S. 2011. Factors Influencing The Intended Use Of Web Portals.Onlineinfo.Rev. 35.2: 237-254.

[48] Liebowitz, J. 2005. Linking Social Network Analysis With The Analytic Hierarchy Process For Knowledge Mapping In Organizations.Journal Of Knowledge Management, 9.1: 76-86.

[49] Lwoga, E. 2013.Measuring The Success Of Library 2.0 Technologies In The African Context: The Suitability Of The Delone And Mclean's Model.Campus-Wide Information Systems, 30.4: 288-307.

[50] Macdonald, J., Sohn, S., And Ellis, P. 2010. Privacy, Professionalism And Facebook: A Dilemma For Young Doctors. Medical Education, 44: 805-813.

[51] Mansfield, S. J., Morrison, S. G., Stephens, H. O., Bonning, M. A., Wang. S. H. And Withers A. H., 2011. Social Media And The Medical Profession.Med J Aust. 194.12: 642-4.

[52] Mckenzie, J. And Van Winkelen, C. 2011. Knowledge Sharing 2.0 And The Social Media Genie. Online, Available

From: Http://Www.Reading.Edu.My/Web/FILES/Corporate/Cl_KM_Forum_Knowledge_Sharing_2_0.Pdf. Accessed 2016-03- 17.

[53] Mohammed, M. A., Huda, I. And Maslinda, M. N. 2015. Electronic Information Sharing Between Public Universities And Ministry Of Higher Education And Scientific Research: A Pilot Study. Journal Of Theoretical Andapplied Information Technology. 
[54] Mohammed, M. A., Maroof, E. Y., Ali, T. And Huda, I. 2015.Electronic Information Sharing Factors That Influence The Participation Behaviour In Higher Education Sector.The Third Information Systems International Conference, 72: 49-58.

[55] Mohamood, K. And Richardson, J. V. 2011. Adoption Of Web 2.0 In U.S. Academic Libraries: A Survey Of ARL Library Websites. Electronic Library And Information Systems, 45.4: 365-375.

[56] Moorhead, S. A., Hazlett, D. E., Harrison, L., Carroll, J. K., Irwin, A., And Hoving, C. 2013. A New Dimension Of Health Care: Systematic Review Of The Uses, Benefits, And Limitations Of Social Media For Health Communication. Journal Of Medical Internet Research, 15.4: 85.

[57] Newbold, K. B. And Campos, S. 2011, Media And Social Media In Public Health Messages: A $\begin{array}{llllll}\text { Systematic Review, } & \text { Viewed } & 24 & \text { November } & \text { 2015, }\end{array}$ Http://Www.Mcmaster.Ca/Mihe/Documents/Publications/Social\%20Media\%20Report.Pdf.

[58] Nye, S. G. 2011. Law And Ethics - Social Media Issues.Journal Of Employee Assistance, 3rd Quarter, 41.3: $\quad$ 14-15. Retrieved 30/7/2016 From Http://Find.Galegroup.Com.Libproxy.Uregina.Ca:2048/Gtx/Infomark.Do?\&Source=Gale\&Srcprod=EAI M\&Prodid=EAIM\&Usergroupname=Ureginalib\&Tabid=T003\&Docid=A263658929\&Type $=$ Retrieve $\&$ Contentset $=$ IAC-Documents $\&$ Version $=1.0$

[59] Oliva, L. M. 2005. Twenty-First Century Challenges To Sharing Information.Information Resources Management Journal, 18.4: 1-4.

[60] Osimo, D. 2008. Web 2.0 In Government: Why And How, Institute For Prospectice Technological Studies (IPTS), Joint Research Center (JRC), European Commission, Seville, Spain.

[61] Panahi, S., Watson, J. And Partridge, H. 2012 Potentials Of Social Media For Tacit Knowledge Sharing Amongst Physicians: Preliminary Findings.23rd Australasian Conference On Information Systems Potentials Of Social Media For Tacit Knowledge Sharing, Geelong. School Of Information Systems Queensland University Of Technology Brisbane, Australia

[62] Panahi, S., Watson, J. And Partridge, H. 2013.Towards Tacit Knowledge Sharing Over Social Web Tools.Journal Of Knowledge Management, 17.3: 379-397.

[63] Pardo, T. A. And Tayi, G. K. 2007. Inter-Organizational Information Integration: A Key Enabler For Digital Government Government Information Quarterly 24.4: 691-715.

[64] Parker, K.R. And Chao, J. T. 2007.Wiki As A Teaching Tool.Interdisciplinary Journal Of Knowledge And Learning Objects, 3: 57- 72.

[65] Pender, N. J., Murdaugh, C. L., And Parsons, M. A. 2002.Health Promotion In Nursing Practice (4th Ed.). Upper Saddle River, NJ:Prentice Hall.

[66] Penzhorn, C. 2013. The Use Of Social Media In Teaching A Campus-Wide Information Literacy Course.Unisa Press ISSN 0027-2639 Mousaion, 31.3: 57-73.

[67] Pew Research Center 2006. Online Papers Modestly Boost Newspaper Readership. Washington, DC2006.

[68] Pew Research Center's Internet And American Life Project 2012.Digital Differences. Washington, DC2012.

[69] Pilch, C. 2009. Social Media Marketing And Web 2.0: What Are They, And How Can They Help You Bring In More Business. Business West.Retrieved September 8, 2015, From Http://Businesswest.Com/Details.Asp?Id=1916.

[70] Purwanti, Y., Pasaribu, N. R. And Lumbantobing, P. 2010. Leveraging The Quality Of Knowledge Sharing By Implementing A Reward Program And Performance Management System. Paper Presented At The 2nd European Conference On Intellectual Capital, ISCTE, Lisbon University Institute, Lisbon, Portugal.

[71] Quan-Haase, A. And Young, A. L. 2010. Uses And Gratifications Of Social Media: A Comparison Of Facebook And Instant Messaging. Bulletin Of Science, Technology \& Society, 30.5: 350-361.

[72] Ressler, P. K. And Glazer, G. 2010. Legislative: Nursing's Engagement In Health Policy And Healthcare Through Social Media. OJIN: The Online Journal Of Issues In Nursing, 16.1

Retrieved 27/5/2016

[73] Rimer, B. K. And Glanz, K. 2005.Theory At A Glance: A Guide For Health Promotion Practice. National Cancer Institute: NIH Publication Nor Notrieved Fromhttp://Www.Cancer.Gov/Cancertopics/Cancerlibrary/Theory.Pdf

[74] Sharma E., 2013. Empirical Study Of Employee Perception Regarding Knowledge Management In India.International Journal Of Economic And Business Management. 1.1: 12-18.

[75] Simon, S. R., Evans, J. S., Benjamin, A., Delano, D. And Bates, D. W. 2009. Patients' Attitudes Toward Electronic Health Information Exchange: Qualitative Study. Journal Of Medical Internet Research, 11.3: 30.

[76] Sjöberg, L. 2010. Social Media In Organizations.Psccritiques, 55.34 No Pagination Specified. 
[77] Small, C. T. And Sage, A. P. 2006. Knowledge Management And Knowledge Sharing: A Review. Information Knowledge Systems Management, 5.3: 153-169.

[78] Sonnenwald, D. H., And Pierce, L. G. 2000. Information Behaviour In Dynamic Group Work Contexts: Interwoven Situational Awareness, Dense Social Networks And Contested Collaboration In Command And Control. Information Processing And Management, 36: 461-479.

[79] Symplur. 2014. \#Hcsm Tweet Chat. Retrieved From Www.Symplur.Com/Healthcare-Hashtags/Hcsm /

[80] Tang, C. And S. Carpendale, 2007.An Observational Study On Information Flow During Nurses' Shift Change.Proceedings Of ACM CHI, Conference On Human Factors In Computing Systems. New York: ACM Press, 219-228.

[81] Urista, M. A., Dong, Q. And Day, K. D. 2009. Explaining Why Young Adults Use Myspace And Facebook Through Uses And Gratifications Theory. Human Communication, 12.2: 215- 229.

[82] Venkatesh, V., Morris, M. G., Davis, G. B., And Davis, F. D. 2003. User Acceptance Of Information Technology: Toward A Unified View. MIS Quarterly, 27.3: 425-478.

[83] Walsham, G. 2001. Making A World Of Difference: IT In A Global Context, Wiley, Chichester

[84] Webster 2002. Concise Edition Dictionary And Thesaurus. Scotland: Geddes And Grosset

[85] Wertheimer, M. 1922. Laws Of Organization In Perceptual Forms. A Source Book Of Gestalt Psychology. London: Routleddge And Kagan Paul. Retrieved Feb. 10, 2016 From Http://Psy.Edu.Asu.Educ/Orclasscs/Weitheimer.Htm

[86] White, N. 2010. Communities And Networks In Support Of Knowledge Sharing.Part 1.Knowledge Management For Development Journal, 6.1: 91-102.

[87] Wilson, T. D. 2010. Information Sharing: An Exploration Of The Literature And Some Propositions. Information Research, 15.4: 440. Available At: Http://Informationr.Net/Ir/15-4/Paper440.Html.

[88] Yang, T. M. And Maxwell, T. A. 2011. Information-Sharing In Public Organizations: A Literature Review Of Interpersonal, Intra-Organizational And Interorganisational Success Factors' Government Information Quarterly 28.2: 164-75

[89] Young, T. B. 2009. Facebook: Ethical And Clinical Considerations. The New Social Worker Online, 16.4. Retrieved 20/2/2016 From

Http://Www.Socialworker.Com/Home/Feature_Articles/Ethics/Facebook\%3A_Ethical_And_Clinical_Co nsiderations/

[90] Yu, T., Lu, L. And Liu, T. 2010.Exploring Factors That Influence Knowledge Sharing Via Weblogs.Computers In Human Behaviour, 26:32-41.

[91] Zhang, J. And Dawes, S. S. 2006. Expectations And Perceptions Of The Benefits And Barriers Of Knowledge Sharing And The Successes In Public Sector Knowledge Networks, Public Performance And Management Review. 29.4: 433-465. 